ESJ Social Sciences

\title{
The Influence of Ownership Concentration on Firm Financial Decisions and Value: Evidence from Nairobi Securities Exchange
}

\author{
Anthony Muriungi \\ Meru University of Science and Technology, Kenya \\ Mirie Mwangi \\ Mary Kinoti \\ Kennedy Okiro \\ University of Nairobi, Kenya
}

Doi:10.19044/esj.2021.v17n32p124

Submitted: 23 November 2020

Accepted: 31 March 2021

Published: 30 September 2021
Copyright 2021 Author(s)

Under Creative Commons BY-NC-ND

4.0 OPEN ACCESS

Cite As:

Muriungi A., Mwangi M., Kinoti M. \& Okiro K. (2021). The Influence of Ownership Concentration on Firm Financial Decisions and Value: Evidence from Nairobi Securities Exchange. European Scientific Journal, ESJ, 17 (32), 124.

https://doi.org/10.19044/esj.2021.v17n32p124

\begin{abstract}
This study paper examines the influence of ownership concentration and firm financial decisions on firm value for firms listed on the Nairobi securities exchange. This study is supported by theoretical literature under the signaling hypothesis, institutional monitoring hypothesis, and agency theory. The study used longitudinal data for listed firms during the ten years (20082017) and regression analysis was used to study the nature and extent of the relationship. The target population was sixty-eight firms that traded equity securities during the period. Empirical results reveal that ownership concentration has no significant positive effect on firm value, but dividend payment significantly influences firm value, and the capital structure only compliments other corporate governance processes in a firm. Firms listed on the Nairobi Securities Exchange have a high level of ownership concentration and this suggests, contrary to the shareholder monitoring hypothesis, large shareholders could be entrenched and, unless other complementary corporate mechanisms are present, large shareholders may not act in the best interest of minority shareholders.
\end{abstract}


Keywords: Ownership concentration, Dividend policy, Capital structure, Firm value

\section{Introduction}

Studies examining ownership concentration and firm value have emphasised the significance of shareholder concentration, capital structure, and dividend policies as corporate control mechanisms, that influence value creation in a firm. Ownership concentration is one of the aspects of ownership structure theory and corporate governance mechanism that are increasingly under the focus of researchers (Machek \& Kubicek, 2018). The identity and level of ownership by large investors have been under sharp scrutiny especially after the failure of Enron, WorldCom, and Parmalat in the United States, and Italy, respectively, between 2001 and 2002. Because of this researchers have increasingly developed a keen interest in understanding the role of influential shareholders in corporations (Dibra, 2016). While corporate governance encompasses both statutory regulation and market-based selfregulation mechanisms, before the failure of Enron in the USA, researchers predominantly preoccupied themselves with the impact of changing statutory regulations. In Kenya, researchers have increasingly taken on the ownership structure of corporations as an object of key research interest in corporate governance processes (Mokaya \& Jangogo, 2015; Kukenyi, Basweti \& Kamau, 2016; Ongore, K'Obonyo \& Ogutu, 2011; Kisavi Mukras \& Oginda, 2013). The motivation for this paper is based on the theoretical postulation under the shareholder monitoring hypothesis (Shliefer \& Vishny, 1986; 1997) and agency cost theory (Jensen \& Meckling, 1976).

This paper sought to examine the complementary role of ownership concentration, debt financing, and dividend policy as a complementary corporate governance mechanism. Globally, studies that have been made to establish the link between ownership, financial decisions, and firm value have provided inconsistent results (Gurgler \& Yurtoglo, 2003; Miguel, Julio \& Chabella, 2005; Gul, 1999; Hong \& Nguyen, 2014). Corporate governance processes are dynamic and statutory regulation is equally dynamic, mostly triggered by changes and challenges within and outside of the business environment. In Kenya, studies in this field include; Yegon Cheruiyot and Sang (2014), who tried to establish the factors that influenced dividend policy at NSE, Ongore, K'Obonyo, and Ogutu (2011) examined the influence of ownership identity and managerial discretion. Kisavi Mukras and Oginda (2013) studied the relationship between ownership concentration and firm performance at the NSE; Karuitha, Onyuma, and Mugo (2013) studied the effect of stock splits on ownership concentration; and Kukenyi Basweti and Kamau (2016) studied the influence of ownership structure and leverage on 
the NSE. Most of the available studies on ownership structure and firm performance in Kenya date back to the period from 2010, implying that studies were motivated by the impact of the Enron scandals and the worldwide financial crises in 2008 which started as a subprime property bubble under the Lehman brothers.

During the period of study, Nairobi Securities Exchange (NSE) had sixty-eight trading firms, but only fifty-seven were active in the market by 2017. During the period, four firms were delisted, eleven more listed in the securities market, some were dormant yet some were suspended. Previous studies have determined that listed firms in Kenya have a high level of ownership concentration, and this has an implication for the financial decisions and performance of the firms (Kisavi, Mukras \& Oginda, 2013; Kiruri, 2013). This study sought to understand the complementary role of ownership concentration, capital structure, and dividend policy for quoted companies in Kenya. The objective of the study was guided by the following research question: What is the effect of ownership concentration, dividend policy, and capital structure decisions on firm value for listed companies at the Nairobi Securities Exchange?

\section{Theoretical Literature}

Debt financing is predominantly hypothesised to be a catalyst for firm performance, and corporate governance theories assert that debt can signal firm wellbeing and could act as a disciplinary mechanism that could encourage managers to work in the best interests of the firm (Morck, Shliefer \& Vishny, 1988), and managers working indifferently from firm value maximization objectives would be disciplined by market forces (Jensen \& Meckling, 1976; Demsetz, 1983). Shliefer and Vishny (1986) hypothesised the role of large institutional shareholders to be that of providing a check on managerial excesses through their ability to monitor. According to Jensen and Meckling (1976), investors can put in place mechanisms that will ensure managers work in the best interests of the firm. These mechanisms include active monitoring, adequate compensation through salaries and bonuses, and curtailing managers' discretion in decision-making. Jensen (1986) further observes that shareholders can induce debt holder monitoring by reducing the amount of free cash flow available to managers, forcing them to seek alternative investment funding in financial markets and therefore get a self-appraisal.

Jensen (1986) contended that dividend payments reduce the amount of free cash flow available to managers, preventing them from being tempted to overburden investment projects motivated by their own interests to the detriment of minority investors. Myers' (1984) pecking order hypothesis suggests that debt is prioritised over equity because it is relatively cheaper and easily available. Ross (1977) observed debt signaling behaviour when 
information asymmetry between managers and shareholders was high. Linter (1956), observed dividend signaling behaviour and hypothesised its significance in value creation. Ownership structure theories have mixed explanations on how ownership control influences key firm decisions and value. Theoretical literature underscores the significance of shareholder monitoring as a corporate governance mechanism, but equally, large shareholder entrenchment is a potential threat to value-maximizing in the firm (Shliefer and Vishny, 1997).

\section{Empirical Literature}

Positive shareholder monitoring, as well as expropriation and entrenchment, are presented in the empirical literature. Studies in more developed economies show a positive relationship between ownership concentration and firm performance, but only when applied with other corporate governance practises like dividend payment (Genc \& Angelo 2012; Miguel, Julio, \& Chabella, 2005; Machek \& Kubicek, 2018). Shareholder monitoring and entrenchment seem to manifest in developing economies. Studies point to the fact that a single dominant shareholder will more likely be entrenched than when checked by a second or a third significantly large shareholder (Georgeta \& Stefan 2014). In Europe, Lopez and Rodriguez (2012) found that in state-controlled economies, higher ownership concentration led to entrenchment and expropriation by dominant shareholders while in free-market economies, higher concentration led to greater firm value. Machek and Kubicek (2018) found increased ownership concentration reduced agency costs in the Czech Republic, but up to a certain level beyond which entrenchment and personal benefit-seeking behaviour ensued. They noted firms with a controlling owner were more profitable than ownership dispersed firms. Genc and Angelo (2012) observed ownership concentration by the largest shareholder had a positive influence on firm value in Italy. Georgeta and Stefan (2014) also found a positive relationship between firm value and large ownership by second and third largest investors and for the total of the largest three shareholders but reduced value when there was one dominant large shareholder in Bucharest Stock Exchange Romania. Kisavi et al. (2013) saw an insignificant effect on shareholder concentration and firm profitability at NSE. Alfaraih, Faisal, and Hesham (2012) observed the effects of different ownership structures on performance in the Kuwait Stock Exchange (KSE) and concluded that the identity of the dominant shareholder was a major determinant of the firm performance alongside the level of shareholder concentration. Alexandra, Lucian, Stefania, and Alma (2019) observed personal seeking behaviour by large and entrenched shareholders in Eastern European economies and positive performance for ownership concentration in Western European countries and noted ownership 
concentration was market-specific and the level of market development affected the influence of ownership concentration. Handayani, Sutrisno, Rahman, and Subekti (2015) noted that a pyramidal ownership structure provided ultimate shareholders with greater cash flow rights, which enhanced their entrenchment and dominance over other shareholders in the Indonesian stock exchange (IDX).

Studies that positively align shareholder value with ownership concentration, dividend policy, and leverage include Maladijan and Rim (2014), who found dividend policies were significantly affected by firm size, risk, and past years' dividends and negatively affected by investment opportunities and firm performance. Hong and Nguyen (2014) noted that managerial ownership had a positive effect on dividend payment, but dividend payment and leverage were negatively related in Vietnam. Sakir and Fadli (2014) observed a significant negative effect of managerial ownership on dividend payment, and that the dominant factor that affected dividend payment was free cash flow. On the other hand, Lopez and Crisostomo (2010) observed that dividend payments signaled growth opportunities for the firm but also denied the manager's total discretion in Brazil. They observed a significant negative relationship between firm investments and the use of debt. Thanatwee (2014) observed that firms with more institutional and individual investors paid fewer dividends but firms with more government and foreign dominance paid more dividends in Thailand. Mukonyi, Basweti, and Kamau (2016) saw an insignificant effect of all different categories of ownership with leverage at NSE.

\section{Research Methodology}

This study followed a longitudinal survey design with quantitative data. This was necessary to discern the pattern of change of the variables over time. The target population for this study was sixty companies listed and trading equity shares on the Nairobi Securities Exchange between $1^{\text {st }}$ January 2008 and $31^{\text {st }}$ December 2017. The target population was chosen because they are public entities with diverse ownership concentration and a common platform for ownership transferability which was of interest to the researcher. Data was obtained through secondary sources, mainly from financial statements of the respective firms at the capital market authority by the use of a pre-set data collection form. This study has four variables and their relationships were tested. The dependent variable is the firm value (Tobin q). The independent variables are ownership concentration (\% of shares held by the top ten shareholders), dividend policy (dividend yield), and debt financing (total debt over equity). 


\section{Data analysis, statistical tests, and models}

Descriptive analysis was used to determine the average values and the dispersion of the variables from their average score. Inferential analysis was carried out by subjecting the variables to simple, multiple, and stepwise regression analysis using longitudinal data. An F-test was used to assess the significance of the overall regression equation. The correlation coefficient $\left(\mathrm{R}^{2}\right)$ and $\mathrm{p}$-values were used to interpret the regression functions at a significance level of .05. All individual regression coefficients were tested for their statistical significance. A summary of statistical tests and regression models used to examine the various relationships is presented below.

(i) Ownership concentration (OC) and firm value

Simple linear regression

$\mathrm{FV}_{\mathrm{it}}=\beta_{0}+\beta_{1} \mathrm{OC}_{\mathrm{it}}+\mathrm{e}_{\mathrm{it}}$

$\mathrm{FV}=$ Firm Value; $\mathrm{OC}=\mathrm{Ownership}$ concentration; $\beta_{1=}$ Regression coefficient; $\mathrm{e}_{1}=$ error term

Relation exist if $\beta_{1}$ is statistically significant, model reliable when $r^{2}$ and F-test significant

(ii) The effect of ownership concentration on firm financial decisions and firm value for firms listed at NSE

Multiple regression analysis

$\mathrm{FV}_{\mathrm{it}}=\beta_{0}+\beta_{1} \mathrm{OC}_{\mathrm{it}}+\beta_{2}$ Dyield $_{\mathrm{it}-1}+\beta_{3} \mathrm{CS}_{\mathrm{it}}+\mathrm{e}_{\mathrm{it}}$

Tobin $\mathrm{q}=$ Firm value; $\mathrm{OC}=$ Ownership concentration; Dyield $=$ Dividend yield; $C S=$ Capital structure; $\beta_{1}, \beta_{2}, \beta_{3}=$ Regression coefficients; $e_{1}=$ error term. A relationship exists if at least one of the regression coefficients are statistically significant and the relationship is strong if $r^{2}$ and F-test are significant where $\mathrm{p}<0.05$.

Firm size is one of the internal factors that influences a firm capacity to generate value for its owners (Harvie, Narjoko \& Oum, 2010). In this study, firm size is used as a control variable to discern and account for the pattern of behaviour of different categories of firms. Larger firms can generate more value than smaller firms by creating market barriers and the use of economies of scale to procure their inputs (Georgeta \& Stefan, 2014). But this benefit may not flow to the owners if they are dispersed and have no control over the managerial activity. It is expected that smaller firms with dominant shareholders are likely to exercise greater control and check on managers' activities, and this could improve firm value. Larger firms will have greater diversity in ownership and a higher level of information asymmetry. Therefore, dividend payments would positively influence firm value as this would help to lower the information gap between managers and shareholders. Longitudinal data suffers from the effect of serial dependency or 
autocorrelation. In this study, the lag variable for Tobin q was used as an independent variable to help improve the model by accounting for the serial dependency of the dependent variable.

\section{Statistical Results}

\section{Data Summary}

Data for the analysis was derived from annual financial reports of listed companies at the Nairobi securities exchange for the trading period between 2008 and 2017. The number of firms listed and actively trading securities at NSE is analysed in table 1.

Table 1: Listed firms at Nairobi Securities Exchange per sector (NSE handbook)

\begin{tabular}{|c|r|r|r|r|r|r|r|r|r|r|}
\hline SECTOR & 2008 & & & & & & & & & \\
& & 2009 & 2010 & 2011 & 2012 & 2013 & 2014 & 2015 & 2016 & 2017 \\
\hline Agriculture & 7 & 7 & 7 & 7 & 7 & 6 & 6 & 6 & 6 & 6 \\
\hline Auto & 4 & 4 & 4 & 4 & 4 & 2 & 2 & 2 & 2 & 2 \\
\hline Banking & 10 & 10 & 10 & 10 & 11 & 11 & 11 & 11 & 11 & 11 \\
\hline Commercial & 7 & 8 & 8 & 8 & 8 & 8 & 8 & 8 & 8 & 8 \\
\hline Construction & 5 & 5 & 5 & 5 & 5 & 5 & 5 & 5 & 5 & 5 \\
\hline Energy And Petroleum & 4 & 4 & 4 & 4 & 5 & 5 & 5 & 5 & 5 & 5 \\
\hline Insurance & 4 & 4 & 4 & 6 & 6 & 6 & 6 & 6 & 6 & 6 \\
\hline Investment & 3 & 3 & 3 & 3 & 3 & 3 & 4 & 4 & 4 & 4 \\
\hline Investment Services & 0 & 0 & 0 & 0 & 0 & 0 & 1 & 1 & 1 & 1 \\
\hline Manufacturing & 7 & 7 & 7 & 7 & 7 & 9 & 9 & 9 & 9 & 9 \\
\hline Telecommunication & 2 & 2 & 2 & 2 & 2 & 1 & 1 & 1 & 1 & 1 \\
\hline Real Estate Inv. Trusts & 0 & 0 & 0 & 0 & 0 & 1 & 1 & 1 & 2 & 2 \\
\hline Total & 53 & 54 & 54 & 56 & 58 & 57 & 60 & 59 & 61 & 60 \\
\hline
\end{tabular}

The number of firms listed increased by 7 during the period. Four firms were delisted. Eleven new firms were listed during the period. At least six firms were either suspended, dormant or inactive during the period. A summary of the descriptive characteristics of the listed firms is provided in table 2 below.

\section{Descriptive Statistics}

A summary of descriptive statistics for ownership concentration, dividend policy, debt policy, and firm value is presented in table 2. This information is derived from listed companies at the NSE for ten years (20082017). 
Table 2: Descriptive Statistics

\begin{tabular}{|c|r|r|r|r|r|r|r|}
\hline & \multicolumn{1}{|c|}{$\mathrm{N}$} & Minimum & Maximum & Mean & $\begin{array}{c}\text { Std. } \\
\text { Deviation }\end{array}$ & \multicolumn{2}{|c|}{ Skewness } \\
\cline { 2 - 8 } & Statistic & Statistic & Statistic & Statistic & Statistic & Statistic & $\begin{array}{c}\text { Std. } \\
\text { Error }\end{array}$ \\
\hline Tobin q & 405 & .060 & 10.10 & 1.68 & 1.56 & 1.99 & .121 \\
\hline $\begin{array}{c}\text { ownership } \\
\text { concentration }\end{array}$ & 405 & .274 & .990 & .72 & .14 & -.743 & .121 \\
\hline Dividend yield & 405 & .007 & .146 & .042 & .026 & 1.2 & .121 \\
\hline Capital structure & 405 & .008 & 10.24 & 2.33 & 2.26 & .98 & .121 \\
\hline Firm size NA & 405 & 7.31 & 11.56 & 9.90 & .72 & -.94 & .121 \\
\hline Valid N ( listwise) & 405 & & & & & & \\
\hline
\end{tabular}

The average Tobin q for listed firms for the ten years was 1.68 with a high of 10.1 and a low of .06. Ownership concentration, measured as the total percentage of the ten largest shareholders, was $72 \%$. The highest was $99 \%$ and the lowest was $27 \%$. The average dividend yield was $4.2 \%$. The highest is $14.6 \%$ and a low of .007. Firms at NSE used higher debt financing. On average debtequity ratio was $2.56 \mathrm{x}$, with a high of $10.2 \mathrm{x}$ and a low of .008 . The average size for companies measured as the logarithm of total assets is 9.88 . The largest firm has 11.56 (shs.363.07 billion) and the lowest was 7.31(Shs. 20.42 billion).

\section{Inferential analysis}

The relationship between ownership and the firm value was analysed by a linear regression model. The statistical hypothesis was to test whether there was a significant relationship between ownership and firm value. The statistical model for the relationship was:

Objective (i) the influence of ownership concentration on firm value

(i) There is no significant effect of ownership concentration on firm value

A simple regression model was used to test the hypothesis $\left(\mathrm{H}_{1}\right)$ : The relationship between ownership concentration (OC) and Firm Value (FV), a regression model of ownership concentration with firm value was applied to the log-transformed values of the study.

Log Tobin $\mathrm{q}_{\mathrm{it}}=\beta_{0}+\beta_{1} \mathrm{OC}_{\mathrm{it}}+\mathrm{e}_{\mathrm{it}}$

A summary of statistical regression analysis using the ordinary least square method (OLS) is provided below in table 4 .

Table 4: Regression analysis for Ownership and Firm Value

\begin{tabular}{|l|c|r|r|r|r|r|}
\hline \multicolumn{2}{|c|}{ Coefficients } \\
\hline \multirow{2}{*}{\multicolumn{2}{|c|}{ Model }} & \multicolumn{2}{|c|}{$\begin{array}{c}\text { Unstandardized } \\
\text { Coefficients }\end{array}$} & $\begin{array}{l}\text { Standardized } \\
\text { Coefficients }\end{array}$ & t & Sig. \\
\cline { 3 - 7 } & & B & Std. Error & Beta & \\
\hline 1 & (Constant) & .087 & .080 & & 1.080 & .281 \\
\hline
\end{tabular}




\begin{tabular}{|c|c|r|r|r|r|r|}
\hline & $\begin{array}{c}\text { Tobinq1(lagged by } \\
\text { 1yr) }\end{array}$ & .908 & .025 & .898 & 36.433 & .000 \\
\cline { 2 - 5 } & $\begin{array}{c}\text { ownership } \\
\text { concentration }\end{array}$ & .113 & .074 & .038 & 1.528 & .128 \\
\hline \multicolumn{6}{|c|}{ a. Dependent Variable: Tobin q } \\
\hline \multicolumn{6}{|c|}{ b. Predictors: (Constant), ownership concentration, Tobinq1 } \\
\hline
\end{tabular}

The model is strong $\left(\mathrm{R}^{2}=.892\right)$ and significant $(\mathrm{F}$-test $=.000)$ parameter estimate for OC $\left(\beta_{1=} .113\right)$ is insignificant $\rho=.128>.05$. Therefore ownership concentration at the NSE has no significant effect on firm value.

Table 5: Statistical output for Ownership and Firm Value under different size categories

\begin{tabular}{|c|c|c|c|c|c|c|}
\hline \multicolumn{7}{|c|}{ Coefficients } \\
\hline & \multirow[t]{2}{*}{ Model } & \multicolumn{2}{|c|}{$\begin{array}{c}\text { Unstandardized } \\
\text { Coefficients }\end{array}$} & $\begin{array}{c}\text { Standardized } \\
\text { Coefficients } \\
\end{array}$ & \multirow[t]{2}{*}{$\mathrm{t}$} & \multirow[t]{2}{*}{ Sig. } \\
\hline & & $\mathrm{B}$ & Std. Error & Beta & & \\
\hline \multirow{3}{*}{1} & (Constant) & -.134 & .139 & & -.967 & .337 \\
\hline & LogTobinq 1 & 1.009 & .046 & .946 & 22.071 & .000 \\
\hline & $\begin{array}{l}\text { Ownership } \\
\text { concentration }\end{array}$ & .127 & .122 & .045 & 1.043 & .301 \\
\hline \multicolumn{7}{|c|}{ a. Dependent Variable: Tobin $\mathrm{q}$} \\
\hline \multicolumn{7}{|c|}{ b. SIZE CATEG = large } \\
\hline \multicolumn{7}{|c|}{$\mathrm{R}^{2}=.892, \mathrm{DW}=2.39, \mathrm{~N}=67$} \\
\hline \multirow{2}{*}{\multicolumn{2}{|c|}{ Model }} & \multicolumn{2}{|c|}{$\begin{array}{c}\text { Unstandardized } \\
\text { Coefficients }\end{array}$} & $\begin{array}{c}\text { Standardized } \\
\text { Coefficients }\end{array}$ & $\mathrm{t}$ & Sig. \\
\hline & & $\mathrm{B}$ & Std. Error & Beta & & \\
\hline \multirow{3}{*}{2} & (Constant) & .213 & .113 & & 1.885 & .061 \\
\hline & Tobinq1 & .865 & .035 & .877 & 24.747 & .000 \\
\hline & $\begin{array}{c}\text { Ownership } \\
\text { Concentration }\end{array}$ & .071 & .106 & .024 & .673 & .501 \\
\hline \multicolumn{7}{|c|}{ a. Dependent Variable: Tobin $\mathrm{q}$} \\
\hline \multicolumn{7}{|c|}{ b. SIZE CATEG = medium } \\
\hline \multicolumn{7}{|c|}{$\mathrm{R}^{2} .762, \mathrm{DW}=2.36, \quad \mathrm{~N}=200$} \\
\hline & Model & \multicolumn{2}{|c|}{$\begin{array}{c}\text { Unstandardized } \\
\text { Coefficients }\end{array}$} & $\begin{array}{c}\text { Standardized } \\
\text { Coefficients } \\
\end{array}$ & $\mathrm{t}$ & Sig. \\
\hline & & $\mathrm{B}$ & Std. Error & Beta & & \\
\hline \multirow{3}{*}{2} & (Constant) & .054 & .186 & & .289 & .773 \\
\hline & Tobinq1 & .890 & .055 & .884 & 16.218 & .000 \\
\hline & $\begin{array}{l}\text { Ownership } \\
\text { concentration }\end{array}$ & .217 & .169 & .070 & 1.288 & .201 \\
\hline \multicolumn{7}{|c|}{ a. Dependent Variable: Tobin $\mathrm{q}$} \\
\hline \multicolumn{7}{|c|}{ b. SIZE CATEG $=$ small } \\
\hline \multicolumn{7}{|c|}{$\mathrm{R}^{2}=.77, \mathrm{DW} 2.060, \mathrm{~N}=82$} \\
\hline
\end{tabular}

None of the parameter estimates for ownership concentration under different size categories has shown any significant effect on firm value, though smaller firms show greater explanatory power than other categories. From the 
statistical analysis of objective (i) hypothesis (i) is statistically accepted ownership concentration as measured by the sum of the top ten shareholders in the firm, and for a different size, categories have no significant effect on firm value.

\section{Ownership Concentration, Financial Decisions, and Firm Value}

To examine the joint effect of ownership concentration and financial decisions on firm value, a multiple regression analysis was used to examine the relationship. Table 6 provides details of the analysis.

Table 6: Ownership Concentration, Financial Decisions, and Firm Value

\begin{tabular}{|c|c|c|c|c|c|c|c|c|}
\hline \multicolumn{9}{|c|}{ Model Summary } \\
\hline Model & $\mathrm{R}$ & \multicolumn{2}{|c|}{ R Square } & \multicolumn{2}{|c|}{$\begin{array}{l}\text { Adjusted R } \\
\text { Square }\end{array}$} & $\begin{array}{l}\text { Std. Error of } \\
\text { Estimate }\end{array}$ & \multicolumn{2}{|c|}{ Durbin-Watson } \\
\hline 1 & $.896^{\mathrm{a}}$ & \multicolumn{2}{|r|}{.803} & \multicolumn{2}{|r|}{.802} & .18182 & & \\
\hline 2 & $.897^{\mathrm{b}}$ & \multicolumn{2}{|r|}{.805} & \multicolumn{2}{|r|}{.803} & .18117 & \multirow{2}{*}{\multicolumn{2}{|c|}{2.255}} \\
\hline 3 & $.897^{\mathrm{c}}$ & \multicolumn{2}{|r|}{.805} & \multicolumn{2}{|r|}{.803} & .18109 & & \\
\hline \multicolumn{9}{|c|}{ a. Predictors: (Constant), Dyield1,Tobinq1 } \\
\hline \multicolumn{9}{|c|}{ b. Predictors: (Constant), Dyield1, Tobinq1, ownership concentration } \\
\hline \multicolumn{9}{|c|}{ c. Predictors: (Constant), Dyield1, Tobinq1, ownership concentration, CS } \\
\hline \multicolumn{9}{|c|}{ d. Dependent Variable: Tobin q } \\
\hline \multicolumn{9}{|c|}{ Coefficients } \\
\hline \multirow{2}{*}{\multicolumn{2}{|c|}{ Model }} & & \multicolumn{3}{|c|}{$\begin{array}{l}\text { Unstandardized } \\
\text { Coefficients }\end{array}$} & \begin{tabular}{|c|} 
Standardized \\
Coefficients \\
\end{tabular} & \multirow[t]{2}{*}{$\mathrm{t}$} & \multirow[t]{2}{*}{ Sig. } \\
\hline & & & & $\mathrm{B}$ & Std. Error & Beta & & \\
\hline \multirow{3}{*}{1} & \multicolumn{2}{|c|}{ (Constant) } & & -.027 & .078 & & -.351 & .726 \\
\hline & \multicolumn{2}{|l|}{ Tobinq1 } & & .906 & .024 & .900 & 37.521 & .000 \\
\hline & \multicolumn{2}{|l|}{ Dyield1 } & & .136 & .036 & .091 & 3.803 & .000 \\
\hline \multirow{4}{*}{2} & \multicolumn{2}{|c|}{ (Constant) } & & -.140 & .099 & & -1.423 & .156 \\
\hline & \multicolumn{2}{|c|}{ Tobinq1 } & & .914 & .024 & .908 & 37.425 & .000 \\
\hline & \multicolumn{2}{|l|}{ Dyield1 } & & .138 & .036 & .093 & 3.873 & .000 \\
\hline & \multicolumn{2}{|c|}{$\begin{array}{c}\text { ownership } \\
\text { concentration }\end{array}$} & & .131 & .070 & .045 & 1.863 & .063 \\
\hline & \multicolumn{2}{|c|}{ (Constant) } & & -.221 & .121 & & -1.826 & .069 \\
\hline & \multicolumn{2}{|l|}{ Tobinq1 } & & .911 & .025 & .904 & 37.041 & .000 \\
\hline 3 & Dyield1 & & & .141 & .036 & .095 & 3.964 & .000 \\
\hline 3 & $\begin{array}{r}\text { ownershi } \\
\text { concentrat }\end{array}$ & & & .148 & .072 & .051 & 2.060 & .040 \\
\hline & $\mathrm{CS}$ & & & .022 & .019 & .028 & 1.149 & .251 \\
\hline
\end{tabular}

Dividend policy has a significant effect on firm value. When the OC variable was included in model (2), the dividend policy coefficient marginally improved to .138 though OC was insignificant. But the inclusion of capital structure, dividend policy, and ownership concentration variable coefficients significantly improved to 14.1 and 14.8 respectively. Suggesting a potential positive joint complementary effect. To understand the relationships under 
different firm characteristics at NSE, the descriptive statistics of the small, medium, and large firms are provided in table 7.

Table 7: Descriptive analysis for size categories

\begin{tabular}{|c|c|r|r|r|r|}
\hline \multicolumn{2}{|c|}{ SIZE } & Tobin q & \multicolumn{1}{c}{$\begin{array}{c}\text { Ownership } \\
\text { Concentration }\end{array}$} & Dividend Yield & Capital Structure \\
\hline \multirow{2}{*}{ Small } & $\mathrm{N}$ & 97 & 97 & 97 & 97 \\
\cline { 2 - 6 } & Mean & 1.72 & .77 & .049 & 1.35 \\
\hline \multirow{2}{*}{ Medium } & $\mathrm{N}$ & 231 & 231 & 231 & 231 \\
\cline { 2 - 6 } & Mean & 1.49 & .71 & .038 & 2.57 \\
\hline \multirow{2}{*}{ Large } & $\mathrm{N}$ & 77 & 77 & 77 & 77 \\
\cline { 2 - 6 } & Mean & 2.20 & .67 & .046 & 2.83 \\
\hline \multirow{2}{*}{ Total } & $\mathrm{N}$ & 405 & 405 & 405 & 405 \\
\cline { 2 - 6 } & Mean & 1.68 & .72 & .042 & 2.33 \\
\hline
\end{tabular}

From table 7 above, smaller firms have the highest level of ownership concentration (.77) and the least level of debt (1.35x). Larger firms have the highest firm value (2.2x) and the highest level of debt usage (2.83x), mediumsized firms have the lowest firm value (1.49x), lowest dividend payment, and a moderate level of ownership concentration. To infer the influence of firm size on the relationship between ownership, financial decisions, and firm value. The firms were categorized into three sizes based on asset values and a regression analysis was done. The results are presented in Table 8 below.

Table 8: Ownership, Financial Decisions and Firm Value,

Regression Analysis by Size category

\begin{tabular}{|c|c|c|c|c|c|c|}
\hline \multicolumn{7}{|c|}{ Coefficients } \\
\hline & \multirow[t]{2}{*}{ Model } & \multicolumn{2}{|c|}{$\begin{array}{c}\text { Unstandardized } \\
\text { Coefficients }\end{array}$} & $\begin{array}{c}\text { Standardized } \\
\text { Coefficients }\end{array}$ & \multirow[t]{2}{*}{$\mathrm{t}$} & \multirow[t]{2}{*}{ Sig. } \\
\hline & & $\mathrm{B}$ & Std. Error & Beta & & \\
\hline \multirow{5}{*}{1} & (Constant) & -1.104 & .301 & & -3.671 & .001 \\
\hline & Tobinq1 & 1.035 & .042 & .970 & 24.488 & .000 \\
\hline & $\begin{array}{l}\text { ownership } \\
\text { concentration }\end{array}$ & .337 & .134 & .119 & 2.510 & .015 \\
\hline & Dyield 1 & .326 & .089 & .149 & 3.670 & .001 \\
\hline & $\mathrm{CS}$ & .077 & .041 & .087 & 1.886 & .064 \\
\hline \multicolumn{7}{|c|}{ a. Dependent Variable: Tobin $\mathrm{q}$} \\
\hline \multicolumn{7}{|c|}{ b. SIZE CATEG = large } \\
\hline \multicolumn{7}{|c|}{$\mathrm{R}^{2}=.907, \mathrm{DW}=2.12, \mathrm{~N}=67$} \\
\hline \multirow{2}{*}{\multicolumn{2}{|c|}{ Model }} & \multicolumn{2}{|c|}{$\begin{array}{l}\text { Unstandardized } \\
\text { Coefficients }\end{array}$} & $\begin{array}{c}\text { Standardized } \\
\text { Coefficients }\end{array}$ & $\mathrm{t}$ & Sig. \\
\hline & & $\mathrm{B}$ & Std. Error & Beta & & \\
\hline \multirow{5}{*}{2} & (Constant) & -.100 & .158 & & -.631 & .529 \\
\hline & Tobinq1 & .862 & .036 & .874 & 24.109 & .000 \\
\hline & $\begin{array}{l}\text { ownership } \\
\text { concentration }\end{array}$ & .062 & .104 & .021 & .598 & .550 \\
\hline & Dyield1 & .147 & .047 & .108 & 3.121 & .002 \\
\hline & $\mathrm{CS}$ & .034 & .029 & .041 & 1.146 & .253 \\
\hline \multicolumn{7}{|c|}{ a. Dependent Variable: Tobin $\mathrm{q}$} \\
\hline
\end{tabular}




\begin{tabular}{|c|c|c|c|c|c|c|}
\hline \multicolumn{7}{|c|}{ b. SIZE CATEG $=$ medium } \\
\hline \multicolumn{7}{|c|}{$\mathrm{R}^{2}=.774, \mathrm{DW}=2.279, \mathrm{~N}=200$} \\
\hline \multirow{2}{*}{\multicolumn{2}{|c|}{ Model }} & \multicolumn{2}{|c|}{$\begin{array}{c}\text { Unstandardized } \\
\text { Coefficients }\end{array}$} & \multirow{2}{*}{$\begin{array}{c}\text { Standardized } \\
\text { Coefficients } \\
\text { Beta }\end{array}$} & \multirow[t]{2}{*}{$\mathrm{t}$} & \multirow[t]{2}{*}{ Sig. } \\
\hline & & $\mathrm{B}$ & Std. Error & & & \\
\hline \multirow{5}{*}{3} & (Constant) & -.124 & .280 & & -.442 & .660 \\
\hline & Tobinq1 & .906 & .058 & .901 & 15.595 & .000 \\
\hline & $\begin{array}{c}\text { Ownership } \\
\text { concentration }\end{array}$ & .262 & . 179 & .084 & 1.463 & .147 \\
\hline & Dyield1 & .079 & .084 & .056 & .941 & .350 \\
\hline & $\mathrm{CS}$ & -.007 & .043 & -.009 & -.153 & .879 \\
\hline \multicolumn{7}{|c|}{ a. Dependent Variable: Tobin $\mathrm{q}$} \\
\hline \multicolumn{7}{|c|}{ b. CATEG = small } \\
\hline \multicolumn{7}{|c|}{$\mathrm{R}^{2}=, \mathrm{DW}=2.028, \mathrm{~N}=82$} \\
\hline
\end{tabular}

The results in table 8 show that larger firms show a positive joint effect of dividend policy and ownership concentration towards firm value. Mediumsized firms had a positive effect on dividend policy, but ownership concentration was insignificant. Smaller firms have no significant effect on either the dividend policy or ownership concentration. The capital structure variable had no significant effect on any of the size categories, though larger firms had a marginally larger effect (.064) than medium and smaller firms (.253) and (.879), respectively. The above results suggest that firms with high ownership concentration that regularly pay dividends and use moderate debt are likely to perform better.

\section{Discussion of the Findings}

This paper examines the effect of ownership concentration and financial decisions on firm value for firms listed on the Nairobi Securities Exchange between 2008 and 2017. Ownership concentration is defined as the percentage of shares held by the top ten shareholders in a firm. The dividend yield is measured as a dividend paid over market value. A simple linear regression model was used to test whether a predictive relationship exists between ownership concentration and firm value, and multiple regression was used to test the predictive ability of ownership concentration on firm value through dividend policy and capital structure. Statistical results indicate ownership concentration has no significant effect on firm value at NSE. Dividend policy has a positive and significant effect on firm value and both capital structure and ownership have a positive complementary effect on firm value.

Ownership concentration is a corporate governance mechanism that finance theory suggests can complement other corporate governance mechanisms in the firm. There is a high-level shareholder concentration at NSE (72\%), a significant improvement from $65.3 \%$ observed by Kisavi et al., 
in 2013. The firm value as indicated by Tobin q was on average 1.68, which compares favourably against Kisavi et al., (2013) 1.32. The effect of ownership concentration on firm value is consistent with the findings of similar studies in developing countries (Machek \& Kubicek, 2018; Alfaraih et. al., 2012; Alexandra et. al., 2019; Kisavi et al., 2013). The findings are further consistent with the shareholder monitoring and entrenchment hypothesis (Shliefer \& Vishny, 1997). Most similar studies in Europe presented a different perspective because ownership concentration had a significant influence on firm value (Genc \& Angelo, 20; Georgeta \& Stefan, 2014; Gurgler \& Yurtoglo, 2003) and therefore consistent with the institutional monitoring hypothesis (Shliefer \& Vishny, 1986). The role of dividend policy as suggested by Linter (1956) is still relevant. Under the signaling hypothesis, dividend payment has a positive effect on firm value. This study's findings are consistent with the theoretical proposition and a large body of empirical evidence. Empirical evidence has not established a clear pattern relating ownership concentration with dividend policy. The findings of this study indicate a marginal increase in dividend coefficient when the ownership concentration variable was introduced in the equation (Table 6, 2). Khan (2006) suggests that the level of ownership concentration with the identity of the large shareholder could positively affect dividend policy when the dominant shareholder was an institution. Sakir and Fadli (2014) observed a significant negative effect of managerial ownership on dividend payment in Indonesia. The interaction between ownership concentration, dividend policy, and the capital structure was positive for firm value, a debt signaling behaviour was observed where the ownership concentration variable attained significance when the capital structure variable was introduced; (Table 6, 3). Hong and Nguyen (2014) found managerial ownership had a positive effect on dividend payment but dividend payment and leverage were negatively related in Vietnam. Thanatwee (2014) found that firms with large government and foreign shareholders paid more dividends than firms with large institutional shareholders and individuals in Thailand, clearly a sharp contrast to the institutional monitoring hypothesis. In this study, size is an important variable. Large firms defined as those with asset values greater than Shs. 31 billion, showed a positive joint effect with dividend policy and ownership concentration. Smaller and medium-sized firms had no positive effect on ownership and capital structure. The findings here have support in the theoretical and empirical evidence. Larger firms are likely to perform better than other firms because of the ability to acquire inputs at lower economies of scale and their monopolistic attitude (Georgeta \& Stefan, 2014). Smaller firms are more likely to be owner concentrated and therefore have greater managerial discretion. Medium-sized firms are likely to be on a growth 
trajectory and could limit dividend payment, which is predominantly established as a major signal for firm performance.

\section{Conclusion}

The empirical literature suggests that the effectiveness of shareholder monitoring is context-specific. What is good in developed markets may potentially be different in developing and underdeveloped markets. For example, in Europe, Lopez and Rodriguez (2012) observe a poor firm value performance for Eastern European countries and a better performance for common law countries with increased ownership concentration. They note corporate financial decisions are taken simultaneously with other corporate governance decisions to effect valuable firm decisions. Other studies also highlight the significance of the identity of the significant shareholder with ownership concentration and indicate that firm performance could be influenced more by the identity of major shareholders, the presence of government ownership, or even foreign investors (Alfaraih, Faisal \& Hesham, 2012; Alexandra et al., 2019; Machek \& Kubicek, 2018; Thanatwee 2014).

Empirical evidence so far is inconclusive and the study is made on the background of a developing market. The findings of this study have important implications for the theory of finance. Most companies quoted at the Nairobi Securities Exchange have a significant large shareholder concentration and are likely to be entrenched and extracting the benefit of control in the absence of complementary corporate governance mechanisms. We note a high dividend omission during the period of the study and most companies maintained a fluctuating dividend policy pattern over the period. The Nairobi Securities Exchange is still a developing market. The study notes security prices have a strong correlation with the previous years' prices suggesting a market in the weak form of efficiency. The study notes that ownership concentration as a corporate governance mechanism is important when combined with other governance mechanisms. In this study, ownership concentration, dividend policy, and debt policy jointly have the potential to safeguard shareholder wealth. Future studies in this field should integrate the identity of the dominant shareholder. Several studies have indicated that the effect of ownership concentration on firm key decisions depends on the identity of the large shareholder (Khan, 2006; Sakir \& Fakir, 2014; Machek \& Kubicek, 2018; Alfaraih et al., 2012; Alexandra et al., 2019). The study encourages policymakers to make policy reforms that will encourage more active regulation and monitoring of large shareholders in the securities market. Researchers in developing countries should empirically test the relevance and applicability of finance theories developed through empirical evidence in developed markets, studies made in developed countries could lead to different theoretical conceptualizations. The study is significant to the theory 
and practice of finance particularly in the field of corporate governance and knowledge gaps and avenues for further research are very apparent.

\section{Acknowledgement}

This paper is part of research funded under a research grant by Meru University of Science and Technology, Directorate of Research, Development and Extension the funding contribution is greatly acknowledged.

\section{References:}

1. Abdul, R. \& Masdar, M. (2015). Effect of ownership structure, company size and profitability on dividend policy in Indonesia Stock Exchange. Australian Journal of Basic \& Applied Sciences. 9 (20), 618 24.

2. Aduda, J., Chogi, R. \& Magutu, O. (2013). An empirical test of competing for corporate governance theories on the performance of firms listed at the Nairobi Securities Exchange. European Scientific Journal 9(13), 107-137

3. Alexandra H., Lucian, B., Stefania C. \& Alma P. (2019), Ownership Concentration and Performance Recovery Patterns in the European Union Sustainability, 11, 953

4. Alfaraih, M., Faisal A. \& Hesham A. (2012). The Influence of Institutional and Government Ownership on Firm Performance: Evidence from Kuwait. International Business Research; Vol. 5, No. 10; Published by Canadian Centre of Science and Education 192

5. Demsetz, H. (1983). The structure of ownership and the theory of the firm. Journal of Law and Economics 26, 375-390.

6. Durbin, J. \& Watson, S. (1951).Testing for serial correlation in the least square regression. Biometrika, 38(2), 159-171.

7. Genc, A. \& Angelo, P. (2012).Ownership concentration and effects over firm performance: Evidence from Italy, European Scientific Journal 8 (22) 39-49

8. Georgeta, V. \& Stefan, C. (2014).The impact of ownership concentration on firm value, empirical study of the Bucharest Stock Exchange-listed companies, Procedia Economics and Finance 15, 271-79

9. Gurgler, K. \&Yurtoglo, B. (2003).Corporate governance and dividend pay-out policy in Germany. European Economic Review 47, 731 - 758

10. Gul, A. (1999). Growth opportunities, capital structure and dividend policies in Japan Journal of Corporate Finance 5, 141-168

11. Handayani, S., Rahman, F. \& Subekti, I. (2015). Integrating mediation and moderation variables to explain the Effect of ownership structure 
on firm value in the Indonesian Stock Exchange. Australian Journal of Basic and Applied Sciences, 9 (23), 729- 737

12. Hong, V. \& Nguyen, T. (2014). Managerial ownership, leverage and dividend Policies: Empirical Evidence from Vietnam's Listed Firms. International Journal of Economics and Finance, 6 (5), 274-284

13. Jensen, M. (1986). Agency costs of free cash flow, corporate finance and takeovers. American Economic Review, 76 (2), 323-329.

14. Jensen, M. \& Meckling, W. (1976). Theory of the firm: managerial behaviour, agency costs and ownership structure, Journal of Financial Economics, (4), 305-60.

15. Juhandi, N., Sudarma, M. \& Aisjah, S. (2013).The Effects of internal factors and stock ownership the structure on dividend policy on the company's value on the Indonesia Stock Exchange, International Journal of Business and Management Invention 2 (11), 6-18

16. Karwitha, J. Onyuma, S. \& Mugo, (2013). Do Stock Splits Affect Ownership Concentration of Firms Listed at the Nairobi Securities Exchange? Research Journal of Finance and Accounting, Vol.4, (15),

17. Khan, T. (2006). Company Dividends and Ownership Structure: Evidence from UK Panel Data, Economic Journal 116 (510), 172-189.

18. Kiruri, R. M. (2013).The effects of ownership structure on bank profitability in Kenya. European. Journal of Management Sciences and Economics, 1(2), 116-127.

19. Kisavi, M., Mukras, S. \& Oginda, M. (2013). Ownership concentration and financial performance of listed firms in Kenya: an econometric analysis using panel data, European Scientific Journal 9 (28), 194-211

20. Linter, J. (1956). Distribution of incomes of corporations among dividends, retained earnings and taxes, The American Economic Review, 46 (2), 97-113.

21. Lopez, F. \& Rodriguez, J. (2012). Ownership structure, financial decisions and institutional setting. An international analysis through simultaneous equations. Economics Research International, 1-12

22. Lopez, F. \& Crisostomo, V. (2010). Do leverage, dividend pay-out and ownership concentration affect firms' value creation? An analysis of Brazilian firms. Emerging Markets Finance and Trade, 46 (3), 80-94

23. Machek, O., Kubicek, A. (2018). The relationship between ownership concentration and performance in the Czech Republic. Journal of International Studies, 11(1) 177-186.

24. Miguel, A., J. Pindado J. and Chabella, T. (2004). Ownership Structure and Firm Value. New Evidence from Spain: Strategic Management Journal 25 (12), 1199-1207

25. Mokaya, M. A, \& Jagongo, A, (2015). The Effect of Ownership Structure on The Financial Performance of Firms Listed at the Nairobi 
Securities Exchange. International Journal of Finance and Accounting 4 (11), 1-17.

26. Morck, R., Shliefer, A. \& Vishny, R. (1988). Management ownership and market valuation: an empirical analysis, Journal of Financial Economics, 20, 293-315.

27. Mukonyi, P., Basweti, K. \& Kamau, S. (2016). The Relationship between Ownership Structure and Leverage of Firms Listed in the Nairobi Securities Exchange, Journal of Economics and Finance 7, (3). 52-59

28. Myers, S. (1984). The capital structure puzzle. Journal of Finance 39, 575-592.

29. Ngugi, R. (2003). Development of the Nairobi Stock Exchange: A historical perspective KIPPRA Discussion Paper No. 27

30. Nkobe, K., Simiyu, K., \& Limo, K., (2013). Dividend policy and share price volatility in Kenya, Research Journal of Finance and Accounting, 4 (6), 115-120

31. Ochieng, E. \& Kinyua, H. (2013). Relationship between inflation and dividend pay-out for firms listed at the Nairobi Securities Exchange, International Journal of Education and Research 1(6), 1-8

32. Ongore, V., K'Obonyo, P. \& Ogutu, M. (2011). Implications of firm ownership identity and managerial discretion on financial performance: empirical evidence from the Nairobi Stock Exchange. International Journal of Humanities and Social Science. 1(13), 187195.

33. Ross, S. (1977). The determination of financial structure: The incentive-signalling approach, Bell Journal of Economics, 8(1), 23-40.

34. Sakir, A. \& Fadli, M. (2014). Influence of managerial ownership, debt policy, size, profitability and free cash flow on dividend policy, a study in Indonesian Manufacturing Industries. Delhi Business Review. 15(1), $15-22$

35. Shliefer, A. \& Vishny, R. (1986). Large shareholders and corporate control. Journal of Political Economy 95, 461-88.

36. Shliefer, A. \& Vishny, R. (1997). A survey of corporate governance. Journal of Finance 52 (2), 737-83

37. Thanatwee, Y. (2013). Ownership structure and dividend policy: Evidence from Thailand International Journal of Economics and Finance, 5(1), 121-132.

38. Yegon, C., Cheruiyot, J. \& Sang, J. (2014). Effects of dividend policy on the firm's performance: Econometric analysis of listed manufacturing firms in Kenya. Research Journal of Finance and Accounting 5(12), 136-144. 